\title{
Meningkatkan Prestasi Belajar Matematika Melalui Penerapan Pendekatan Kontekstual
}

\author{
Sugiyanto ${ }^{1 *}$ \\ ${ }^{1}$ SMP Negeri 2 Singaraja, Singaraja, Indonesia
}

\section{ART I CLE I N F O}

Article history:

Received April 19, 2021

Revised April 25, 2021

Accepted June 22, 2021

Available online August 25, 2021

Kata Kunci:

Pendekatan Kontekstual,

Prestasi Belajar

Keywords:

Contextual Teaching and

Learning, Learning Achievement

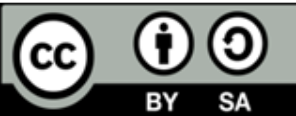

This is an open access article under the CC BY-SA license.

Copyright $(2021$ by Author. Published by Universitas Pendidikan Ganesha.

\begin{abstract}
A B S T R A K
Paradigma terhadap pembelajaran matematika yang terkesan menyeramkan serta kurangnya kemampuan guru dalam memilih metode serta pendekatan pembelajaran yang tepat, berakibat pada rendahnya prestasi belajar matematika siswa sekolah menengah pertama. Sehingga tujuan dari penelitian ini yakni untuk meningkatkan prestasi belajar siswa sekolah menengah pertama. Penelitian ini menggunakan jenis penelitian tidakan kelas dengan jumlah subjek sebanyak 30 orang. Penelitian dilakukan dalam dua siklus yang masing-masing dilakukan dengan tahapan perencanaan, pelaksanaan, observasi dan refleksi. Setiap siklus dilaksanakan melalui dua kali pertemuan tatap muka. Data hasil penelitian dikumpulkan dengan menggunakan metode tes, yakni test prestasi belajar Matematika yang telah disusun pada bagian lampiran RPP dan untuk menganalisis data hasil penelitian menggunakan Metode analisis data deskriptif kuatitatif, dalam bentuk rata-rata prestasi belajar dan prosentase ketuntasan belajar klasikal. Perhitungan rata-rata prestasi belajar dan ketuntasan belajar klasikal setiap kali pertemuan dengan memanfaatkan rumus pada program aplikasi excel. Hasil penelitian menunjukkan bahwa, pada siklus I terjadi peningkatan persetase dari $53,33 \%$ menjadi $60,00 \%$. Oleh karenan hasil penelitian siklus-1 belum memenuhi indikator keberhasilan maka penelitian dilanjutkan pada siklus-2 dengan memperbaiki kelemahan-kelemahan yang terlihat pada siklus-1. Selanjutnya pada siklus II terjadi peningkatan prestasi belajar matematika dengan persentase ketuntasan belajar menjadi 86,67 \%. Sehingga dapat disimpulkan bahwa penerapan pendekatan Kontekstual dapat meningkatkan prestasi belajar Matematika siswa sekolah menengah pertama.
\end{abstract}

\begin{abstract}
A B S T RACT
The paradigm of learning mathematics that seems scary and the lack of teacher ability in choosing the right learning methods and approaches, results in the low mathematics learning achievement of junior high school students. So the purpose of this research is to improve the learning achievement of junior high school students. This study uses the type of classroom action research with the number of subjects as many as 30 people. The research was conducted in two cycles, each of which was carried out with stages of planning, implementation, observation and reflection. Each cycle is carried out through two face-to-face meetings. The research data were collected using the test method, namely the mathematics learning achievement test which had been compiled in the appendix of the RPP and to analyze the research data using the quantitative descriptive data analysis method, in the form of the average learning achievement and the percentage of classical learning completeness. Calculation of the average learning achievement and classical learning completeness at each meeting by utilizing the formula in the excel application program. The results showed that, in the first cycle there was an increase in the percentage from $53.33 \%$ to $60.00 \%$. Because the results of the research cycle-1 did not meet the indicators of success, the research was continued in cycle-2 by improving the weaknesses seen in cycle-1. Furthermore, in the second cycle there was an increase in learning achievement in mathematics with the percentage of learning completeness to be $86.67 \%$. So it can be concluded that the application of the Contextual approach can improve the mathematics learning achievement of junior high school students.
\end{abstract}




\section{PENDAHULUAN}

Perkembangan berbagai teknologi informasi dan komunikasi di era globalisasi seperti saat ini menuntut adanya peningkatan terhadap kualitas sumber daya manusia. Era globalisasi membutuhkan sumber daya manusia yang mampu berpikir kritis dan kreatif dalam menghadapi berbagai perubahan yang ada (Mardhiyah et al., 2021). Pembentukan sumber daya manusia yang berkualitas dapat dilakukan melalui proses pendidikan dan pengajaran (Yudha, 2019). Pendidikan diartikan sebagai suatu usaha sadar dan terecana untuk mewujudkan suasana belajar dan proses pembelajaran agar peserta didik mampu secara aktif mengembangkan potensi dirinya untuk memiliki kekuatan spiritual keagamaan, pengendalian diri, kepribadian, kecerdasan, akhlak mulia serta ketrampilan yang diperlukan dirinya, masyarakat, bangsa dan Negara (Dikta, 2020; Suluh, 2018). Di Indonesia sendiri terdapat tiga jenjang pendidikan, yang wajib ditempuh oleh masyarakat Indonesia, yakni pendidikan dasar, sekolah menengah pertama dan sekolah menengah atas. Di ketiga jenjang pendidikan tersebut peserta didik diajarkan untuk mampu memecahkan masalah dengan pola pikir yang aktif, kreatif, logis, serta sistematis. Salah satu mata pelajaran yang mampu mengembangkan pola pikir yang aktif, kreatif, logis, serta sistematis adalah mata pelajaran matematika (Eismawati et al., 2019; Guntur et al., 2020; Isnaeni et al., 2018). Matematika merupakan akar dari berbagai bidang ilmu dan mendasari muncul serta berkembangnya ilmu pengetahuan lain (Andrijati, 2014; Nahdi, 2019; Yuwono et al., 2018).

Kurikulum Pendidikan Nasional menetapkan bahwa pembelajaran Matematika diarahkan untuk mencapai kompetensi lulusan siswa yang memiliki keseimbangan soft skills dan hard skills yang meliputi aspek kompetensi sikap, pengetahuan, dan keterampilan dalam bidang matematika (Purbaningrum, 2017). Hal ini dilaksanakan melalui pendekatan ilmiah atau pendekatan saintifik. Pendekatan ini diterapkan dalam rangka mencapai tujuan pembelajaran seperti; meningkatkan kemampuan intelektual, khususnya kemampuan tingkat tinggi siswa, membentuk kemampuan siswa dalam menyelesaikan suatu masalah secara sistematik, memperoleh hasil belajar yang tinggi, dan melatih siswa dalam mengkomunikasikan ide-ide nya, yang dimaksudkan untuk mempersiapkan siswa mampu merefleksikan pengalamannya sendiri dan pengalaman orang lain, mengungkapkan gagasan-gagasan dan perasaan serta memahami beragam nuansa makna (Azizah et al., 2018; Puspita et al., 2018; Siswono, 2016). Pembelajaran Matematika memiliki kegunaan untuk membantu siswa mengenal dirinya, budayanya, budaya orang lain, mengemukakan gagasan dan perasaan, berpartisipasi dalam masyarakat, membuat keputusan yang bertanggung jawab pada tingkat pribadi, sosial, menemukan serta menggunakan kemampuan analitic dan imajinatif yang ada dalam dirinya (Mansur, 2018; Sumartini, 2017). Seiring dengan peran penting mata pelajaran Matematika dan tujuan pembelajaran Matematika yang telah disampaikan, maka proses pembelajaran seharusnya diarahkan dalam rangka mencapai tujuan dimaksud. Guru mata pelajaran Matematika, harus memahami bagaimana materi pelajaran dibelajarkan dengan baik, sehingga mencapai hasil sesuai dengan keinginan. Hal yang terpenting adalah guru mampu memilih strategi, metode, model, dan tehnik pembelajaran berdasarkan karakteristik siswa dan materi yang dibelajarkan.

Namun pada proses pelaksanaannya masih terdapat beberapa kelemahan-kelemahan dalam pembelajaran matematika yang kurang disadari oleh guru, seperti kurang cocoknya strategi, metode, model, dan tehnik pembelajaranyang dipilih untuk diterapkan oleh guru, sehingga berakibat pada rendahnya kualitas pembelajaran, yang ditandai dengan rendahnya kreativitas, motivasi serta prestasi belajar siswa. Hal ini sejalan dengan temuan dilapangan dimana pembelajaran Matematikan di SMP Negeri 2 Singaraja pada smester genap tahun pelajaran 2017/2018, terdapat satu kelas yang paling mengkhawatirkan, yakni kelas VIII-8. Hal ini dibuktikan dengan data hasil penilaian awal smester genap tahun pelajaran 2017/2018 dengan kompetensi dasar Teorema pytagoras, ternyata hasil evaluasi menyatakan bahwa nilai rata-rata-rata hanya 66,25 dari KKM yang mesti dicapai 70. Persentase ketuntasan belajar kalsikal baru mencapai 53,33\%, dari prosentase ketuntasan belajar klasikal ideal yang mesti dicapai adalah $85 \%$. Setelah dilaksanakan refleksi terhadap proses pembelajaran yang dilaksanakan sebelumnya, dan dikuatkan dengan hasil wawancara terhadap siswa, ternyata secara umum siswa menyatakan kurang tertarik dengan pembelajaran Matematika, karena materi terlalu sulit untuk dipahami. Hal ini disebabkan karena guru kurang mampu memilih pendekatan pembelajaran yang tepat, sehingga dibutuhkan inovasi pembelajaran dengan menerapkan pendekatan pembelajaran yang sesuai dengan proses pembelajaran matematika.

Salah satu pendekatan yang sesuai dengan pembelajaran matematika adalah pendekatan konstektual. Pendekatan Contextual Teaching and Learning merupakan pendekatan yang memanfaatkan kondisi kehidupan siswa sebagai salah satu komponen pembelajaran sehingga keterlibatan siswa dalam pembelajaran dapat dimaksimalnya (Ayuningrum et al., 2019). Pendekatan Contextual atau Contextual Teaching and Learning merupakan landasan filosofi construktivisme, dimana dalam belajar dengan menggunakan filosofi construktivisme terdapat 5 elemen belajar yang penting untuk diketahui (Nurdiana, 
2021). Ke-5 elemen belajar itu adalah pengaktifan pengetahuan yang sudah ada; pemerolehan pengetahuan baru dengan cara mempelajari secara keseluruhan dahulu, kemudian memperhatikan detailnya; pemahaman pengetahuan yaitu dengan cara menyusun konsep sementara (hipotesis), melakukan sharing kepada orang lain agar mendapat tanggapan (validasi) dan atas tanggapan tersebut dilakukan revisi dan dikembangkan; mempraktekkan pengetahuan dan pengalaman tersebut, serta; melakukan refleksi terhadap strategi pengembangan pengetahuan (Afriani, 2018; Azmir \& Yolanda, 2021).

Pembelajaran matematika dengan menggunakan pendekatan Contextual Teaching and Learning akan membantu siswa untuk memahami kondisi lingkungan sekitar dan mengatasi berbagai permasalahan di dalamnya dengan cara matematis seperti berfikir secara mandiri, kritis, kreatif, inovatif dan sistematis sehingga mampu meningkatkan hasil serta prestasi belajarnya di sekolah. Hal ini sejalan dengan penelitian yang dilakukan oleh (Sugandi \& Bernard, 2018) yang menunjukkan bahwa pendekatan Contextual Teaching and Learningsecara signifikan mampu meningkatkan kemampuan pemahaman matematik siswa serta mampu mengembangkan kemampuan komunikasi matematis siswa yang berpengaruh pada peningkatan prestasi belajar. Penelitian relevan selanjutnya yakni penelitian yang dilakukan oleh (Santoso, 2020) yang juga menunjukkan hasil bahwa penggunaan pendekatan kontekstual dapat meningkatkan hasil belajar siswa, sehingga siswa mampu mencapai ketuntasan minimal. Penelitian relevan lainnya yakni penelitian yang dilakukan oleh (Agnesti \& Amelia, 2020), dimana hasil dari penelitiannya menunjukkan bahwa pembelajaran matematika dengan menggunakan pendekatan Contextual Teaching and Learningsecara signifikan mampu meningkatkan kemampuan pemecahan masalah siswa, yang ditunjukkan dengan adanya peningkatan kemampuan siswa dalam menyelesaikan soal cerita.

Berdasarkan hasil penelitian yang relevan tersebut, dapat disimpulkan bahwa pembelajaran matematika dengan menggunakan pendekatan Contextual Teaching and Learningterbukti mampu meningkatkan hasil belajar, serta kemampuan pemecahan masalah siswa. Adapun tujuan dari penelitian ini yakni untuk meningkatkan prestasi belajar Matematika siswa Kelas VIII-8 SMP Negeri 2 Singaraja pada Semester genap Tahun pelajaran 2017/2018 dengan penerapan pendekatan Contextual. Hasil dari penelitian ini dapat digunakan sebagai pedoman pelaksanaan pembelajaran matematika, guna meningkatkan hasil belajar siswa.

\section{METODE}

Penelitian ini menggunakan jenis penelitian tindakan kelas yang dilaksanakan untuk meningkatkan kualitas pembelajaran matematika. Subjek dalam penelitian ini adalah kelas yang mengalami permasalahan dalam proses pembelajaran matematika, yakni siswa kelas VIII-8 SMP Negeri 2 Singaraja, dengan jumlah keseluruhan adalah 30 rang siswa yang terdiri dari 9 orang siswa laki-laki dan 21 orang siswa perempuan. Penelitian ini dilaksanakan secara berdaur, selama dua siklus dimana setiap siklus dilaksanakan dalam dua kali pertemuan, masing-masing siklus dilaksanakan melalui empat tahapan yakni; perencanaan, pelaksanaan, observasi dan refleksi. Secara lebih rinci tahapan pelaksanaan siklus dapat dilihat pada gambar 1 .

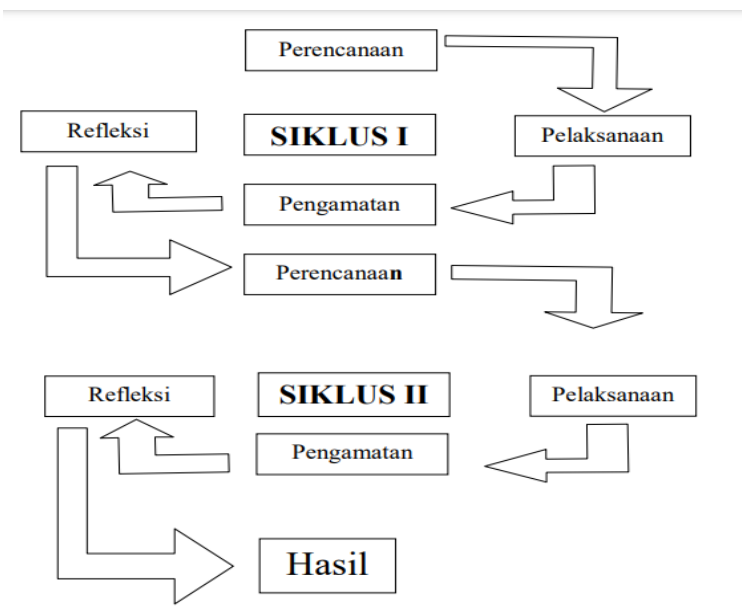

Gambar 1. Rancangan Penelitian Tindakan Model Kurt Lewin

Pada tahap perencanaan, kegiatan yang dilakukan adalah melakukan pengamatan pendahuluan 
untuk mengetahui kondisi awal dan keadaan kelas penelitian; menyusun silabus dan rencana pembelajaran; serta menyusun instrumen penelitian. Selanjutnya pada tahap pelaksanaan, guru memberikan tindakan berupa pembelajaran dengan pendekatan Contextual berdasarkan skenario pembelajaran seperti; kegiatan pembukaan, kegiatan inti dan penutup. Pada kegiatan Inti kegiatan pembelajaran diawali dengan pengaktifan pengetahuan yang telah dimiliki siswa sebelumnya (Construktivisme) melalui memberikan pertanyaan(Quistioning), membagikan bahan ajar, dimana dengan bahan ajar tersebut siswa berproses menemukan sendiri materi pembelajaran (Inquiry). Selanjutnya siswa diberikan kesempatan untuk membentuk kelompok diskusi dengan jumlah anggota kelompok antara 4-6 orang secara heterogen. Setiap kelompok diberikan kesempatan untuk memperagakan bagaimana menyampaikan hasil kerja mereka. Pada bagian akhir dari langkah pendekatan ini adalah melakukan penilaian secara utuh yakni menilai proses diskusi atau tanya jawab di kelompoknya masingmasing, dan menilai pemahaman siswa dalam menguasai materi lingkaran, atau hasil pembelajaran yang telah dilaksanakan(authentic assesment).

Selama pelaksanaan pembelajaran berlangsung peneliti juga melaksanakan observasi terhadap kegiatan belajar siswa. Hasil observasi yang didapatkan yakni berupa data tentang proses pembelajaran dan hasil belajar menyangkut pemahaman siswa terhadap materi lingkaran yang sedang dibelajarkan. Selanjutnya tahap refleksi melalui menghitung rata-rata hasil belajar, dan prosentase ketuntasan belajar klasikal.Evaluasi keberhasilan penelitiannuntuk menentukan penelitian dilanjutkan ke siklus selanjutnya atau dihentikan. Data prestasi belajar dikumpulkan dengan metode test, selanjutnya dilakukan analisis secara deskriptif kuantitatif, dengan menghitung rata-rata dan prosentase ketuntasan belajar klasikal. Untuk menghitung rata-rata prestasi belajar digunakan rumus: Rerata $=\frac{\text { jumlah nilai Tolal }}{\text { jumlah subjek }}$ dan untuk prosentase ketuntasan belajar klasikal dengan rumus : \% Ketuntasan Klasikal $=\frac{\text { jumlah siswa tuntas }}{\text { jumlah subjek }} \times 100$. Keberhasilan penelitian penelitian ini ditentukan dengan perolehan data hasil penelitian dengan indikator jika telah mencapai hasil rata-rata minimal sama dengan KKM atau lebih yakni 70, dan ketuntasan belajar klasikal sama dengan $85,00 \%$. atau lebih.

\section{HASIL DAN PEMBAHASAN}

Kondisi awal subjek penelitian adalah siswa belum mampu mencapai KKM yang dipersyaratkan yakni 70 . ketuntasan belajar klasikal hanya 53,33\% dan sejumlah 14 orang siswa yang belum berhasil, yang harus diberikan pembelajaran remidial. Jumlah ini cukup tinggi sehingga remidial yang dilaksanakan adalah remidial dengan pola memberikan pembelajaran ulang tentang materi pembelajaran Teorema Pythagoras. Hasil penelitian siklus I Rata-rata prestasi belajar Matematika Rerata Nilai $=\frac{2098}{30}=69,93$. Dan \% Ketuntasan Klasikal $=\frac{18}{32} \times 100$ adalah : 60,00 \%. Berdasarkan hasil analisis rata-rata prestasi belajar dan persentase ketuntasan belajar klasikal pada siklus I ini belum memenuhi indikator keberhasilan penelitian, sehingga penelitian harus dilanjutkan ke siklus II.

Pelaksanaan penelitian di siklus I, sudah direncanakan secara baik namun pelaksanaannya belum optimal. Hal ini dikarenakan penerapan pembelajaran Contextual Teaching and Learning merupakan hal baru bagi siswa, sehingga siswa belum terbiasa dengan proses pembelajaran yang dilakukan. Kurang terbiasanya siswa dalam menggunakan pendekatan Contextual Teaching and Learning berakibat pada belum tercapainya indikator keberhasilan penelitian tes prestasi belajar Matematika. Namun jika dibandingkan dengan hasil penilaian prestasi belajar Matematika awal sebelum dilaksanakan pembelajaran dengan pendekatan Contextual Teaching and Learning ternyata siswa sudah mengalami peningkatan dari sisi rata-rata sebanyak 3,68 yakni dari rata-rata awal 66,25 menjadi 69,93 dan dari sisi persentase ketuntasan belajar klasikal sebanyak 6,67 \% yakni dari ketuntasan belajar klasikal awal hanya $53,33 \%$ menjadi $60,00 \%$. Keberhasil ini sangat dipengaruhi oleh pemanfaatan pendekatan pembelajaran yang dimanfaatkan. Namun peningkatan tersebut belum mampu mencapai indikator penelitian, karena beberapa hal permasalahan yang harus segera ditanggulangi.

Adapun kelemahan-kelemahan lain yang muncul pada siklus I yakni a) siswa belum terbiasa dengan pendekatan pembelajaran Contextual Teaching and Learningterutama dalam langkah membangun pengetahuan sendiri Konstruktivis berdasarkan pemahaman sebelumnya, siswa masih perlu dibimbing dengan melalui memberikan klu, b) Masih muncul kebiasaan siswa yang selalu menunggu perintah guru untuk melaksanakan proses pembelajaran, sehingga perlu dibiasakan secara terus menerus, serta c) Siswa masih terpaku kepada bahan ajar berupa buku paket, dan LKS saja, belum mampu mengakses bahan ajar berbasis IT yang bersumber dari internet, d) pada saat siswa pada kelompok lain yang menyajikan hasil diskusinya di depan kelas, siswa dari kelompok lainnya masih belum sungguh-sungguh menanggapi penyajian tersebut, sehingga penyajian terkadang terkesan asal-asalan, dan kurang menantang bagi 
kelompok penyaji, e) serta beberapa siswa terutama yaang memiliki kemampuan lebih terlihat masih mendominasi dalam diskusi.

Mengacu dari kelemahan tersebut, maka perlu dilaksanakan siklus II dengan memperbaiki kelemahan-kelemahan yang masih ada. Analisis terhadap kelemahan-kelemahan tersebut secara umum tterletak pada pemanfaatan pendekatan pembelajaran Contextual Teaching and Learning ini bagi siswa kelas VIII-8 merupakan suatu hal yang baru, sehingga perlu dibiasakan. Terdapat penilaian berupa Authentic assesmen yang juga merupakan hal baru, karena sebelumnya penilaian hanya berupa test yang mengukur pemahaman terhadap pengetahuan saja sehingga penilaian sikap dalam bentuk aktivitas, peran serta siswa dalam diskusi sering diabaikan, demikian juga penilaian terhadap keterampilan siswa membangun pengetahuan, mengumpulkan fakta-fakta menjadi pengetahuan, keterampilan dalam diskusi, bertanya dan kegiatan lainnya. Melalui mnyempurnakan perencanaan secara matang, dan membiasakan siswa untuk mengikuti langkah-langkah pendekatan Contextual Teaching and Learning, maka mulai nampak adanya hasil yang memenuhi indikator keberhasilan penelitian.

Pada pembelajaran siklus II nilai prestasi belajar matematika pada pertemuan ke-1 dan pertemuan ke-2, diperoleh rata-rata prestasi $\frac{2222}{30}=74,07$ dan persentase ketuntasan belajar klasikal $\frac{26}{30} \times 100=86,67 \%$. Prestasi belajar siswa mengalami peningkatan dari sisi rata-rata prestasi belajar sebanyak 4,33 yakni dari rata-rata 69,93 pada siklus I menjadi 74,07 di akhir siklus II. Selanjutnya dari sisi ketuntasan belajar klasikal meningkat sebanyak 26,67 \% yakni dari 60,00 \% di siklus I menjadi 86,67 di siklus II. Hasil analisis rata-rata prestasi belajar dan persentase ketuntasan belajar klasikal pada siklus II penelitian di sudah memenuhi indikator keberhasilan penelitian, sehingga penelitian tidak dilanjutkan ke siklus berikutnya. Hasil penelitian ini membuktikan bahwa pendekatan pembelajaran Contextual Teaching and Learning jika diterapkan dalam proses pembelajaran akan berpengaruh secara signifikan terhadap prestasi belajar siswa. Hasil yang diperoleh dalam penelitian ini sejalan dengan hasil penelitian (Santoso, 2020) yang juga menunjukkan hasil bahwa penggunaan pendekatan Contextual Teaching and Learning dalam pembelajaran matemastika secara seignifikan telah mampu meningkatkan hasil belajar serta prestasi belajar siswa sekolah mengah pertama, yang juga ditujunkkan dengan adanya peningkatan ratarata nilai siswa di setiap siklusnya. Penelitian relevan lainnya yakni penelitian yang dilakukan oleh (Agnesti \& Amelia, 2020; Sugandi \& Benard, 2018), dimana hasil penelitiannya menunjukkan bahwa selain mampu meningkatkan prestasi belajar penggunaan pendekatan Contextual Teaching and Learning juga mampu meningkatkan kemampuan matematis serta kemampuan pemecahan masalah siswa. Peningkatan kemampuan matematis serta kemampuan pemecahan masalah secara tidak langsung akan berdampak pada peningkatan hasil belajar siswa.

Peningkatan prestasi belajar siswa melalui penggunaan pendekatan Contextual Teaching and Learning tidak telapas dari penggunaan langkah-langkah penerapan pendekatan pembelajaran yang mampu merubah paradigma pembelajaran matematika yang kurang menarik, kurang diminati oleh siswa, pembelajjaan yang sangat sulit dan menakutkan, menjadi pembelajaran yang sangat menarik karena siswa merasakan adanya manfaat terhadap kehidupannya yang didapat dari pembelajaran (Artikasari \& Saefudin, 2017; Saputri et al., 2018; Wirdaningsih et al., 2017). Siswa tidak lagi memandang Mata pelajaran Matematika yang menakutkan, hal ini karena pembelajaran dikemas dengan mananfaatkan konteks kehitupan siswa. Pembelajaran dengan pendekatan Contextual Teaching and Learning mampu memberikan pembelajaran yang lebih bermakna pada siswa. Hal ini dikarenakan dalam pembelajaran dengan menggunakan pendekatan Contextual Teaching and Learning siswa dituntut untuk dapat menangkap hubungan antara pengalaman belajar di sekolah dengan kehidupan nyata (Hanik et al., 2018). Hal ini sangat penting, sebab dengan dapat mengorelasikan materi yang ditemukan dengan kehidupan nyata, bukan saja bagi siswa materi itu akan berfungsi secara fungsional, akan tetapi materi yang dipelajarinya akan tertanam erat dalam memori siswa, sihingga tidak akan mudah dilupakan. Selain itu pembelajaran dengan menggunakan pendekatan Contextual Teaching and Learning mampu meningkatkan keaktifan serta produktifitas siswa, sehingga mampu menumbuhkan penguatan konsep melalui proses menemukan pengetahuan sendiri (Sofia, 2020; Wasilati et al., 2018).

\section{SIMPULAN}

Mengacu kepada deskripsi datahasil penelitian siklus I dan siklus II, maka dapat disimpulkan bahwa Prestasi belajar Matematika siswa Kelas VIII-8 SMP Negeri 2 Singaraja pada semester genap Tahun Pelajaran 2017/2018 dapat ditingkatkan melalui penerapan pendekatan Contextual. Saran disampaikan kepadaGuru mata pelajaran matematika, agar senantiasa menganalisis setiap permasalahan yang terjadi dalam proses pembelajaran, selanjutnya memanfaatkan pendekatan pembelajaran yang tepat sesuai dengan hasil analisis terhadap permasalahan tersebut. Pendekatan Contextual telah terbukti dapat 
menanggulangi permasalahan pembelajaran, maka sewajarnya menjadi refrensi/pertimbangan.Guru mata pelajaran secara umum, agar mencoba pendekatan Contextual ini sehingga kualitas pembelajaran dapat ditingkatkan.Peneliti lain, agar mengupayakan pelaksanaan penelitian pemanfaatan pendekatan Contextual ini dalam proses pembelajaran dengan memperhatikan hal-hal yang belum sempat diteliti pada penelitian ini, juga untuk menguji validitas hasil penelitian ini, sehingga pendekatan Contextual betulbetul sangat efektif dalam menanggilangi masalah pembelajaran.Pihak terkait, dalam hal ini kepala sekolah agar menjadikan hasil penelitian ini sebagai refrensi dalam meningkatkan kualitas lulusan yang diawali dengan peningkatan proses pembelajaran, juga agar memfasilitasi setiap usaha guru yang bertujuan berkreasi dalam menciptakan pembelajaran yang efektif.

\section{DAFTAR RUJUKAN}

Afriani, A. (2018). Pembelajaran Kontekstual (Contextual Teaching and Learning) dan Pemahaman Konsep Siswa. Jurnal Al Muta'aliyah STAI Darul Kamal NW Kembang Kerang, I(3), 80-88. http://ejournal.kopertais4.or.id/sasambo/index.php/mutaaliyah/ article/view/3005/2208.

Agnesti, Y., \& Amelia, R. (2020). Penerapan Pendekatan Kontekstual dalam Menyelesaikan Soal Cerita pada Materi Perbandingan dan Skala terhadap Siswa SMP. Jurnal Pendidikan Matematika, 9(2), 347-358. https://doi.org/https://doi.org/10.31980/mosharafa .v9i2.748.

Andrijati, N. (2014). Penerapan Media Pembelajaran Inovatif Dalam Pembelajaran Matematika Sekolah Dasar Di Pgsd Upp Tegal. Jurnal Penelitian Pendidikan Unnes, 31(2), 125160. https: //doi.org/10.15294/jpp.v31i2.5696.

Artikasari, E. A., \& Saefudin, A. A. (2017). Menumbuh Kembangkan Kemampuan Berpikir Kreatif Matematis Dengan Pendekatan Contextual Teaching And Learning. Jurnal Math Educator Nusantara, 3(2). https://doi.org/10.29407/jmen.v3i2.800.

Ayuningrum, Y., Supriyadi, \& Darsono. (2019). Pengaruh Pendekatan Kontekstual Dengan Menggunakan Media Realia Terhadap Hasil Belajar Matematika. Joernal Concept And Communication, null(23), 301-316. https://doi.org/10.15797/concom.2019..23.009.

Azizah, M., Sulianto, J., \& Cintang, N. (2018). Analisis Keterampilan Berpikir Kritis Siswa Sekolah Dasar pada Pembelajaran Matematika Kurikulum 2013. Jurnal Penelitian Pendidikan, 35(1), 61-70. https: //doi.org/10.15294/jpp.v35i1.13529.

Azmir, S., \& Yolanda, N. S. (2021). Pendekatan Contextual Teaching And Learning (CTL) Dalam Pembelajaran Operasi Bentuk Aljabar. Ekasakti Education Journal, 1(1), 16-23. https://doi.org/https://doi.org/10.31933/eej.v1i1.165.

Dikta, P. G. A. (2020). Pembelajaran Berorientasi Tri Hita Karana Sebagai Upaya Penguatan Kualitas Pendidikan Dasar Pada Abad Ke-21. Pendasi: Jurnal Pendidikan Dasar Indonesia, 4(1), 127. https://doi.org/https://doi.org/10.23887/jpdi.v4i1.3103.

Eismawati, E., Koeswanti, H. D., \& Radia, E. H. (2019). Peningkatan hasil belajar matematika melalui model pembelajaran problem based learning ( PBL ) siswa kelas 4 SD. Jurnal Mercumatika: Jurnal Penelitian Matematika Dan Pendidikan Matematika, 3(2), 71-78. https://doi.org/https://doi.org/10.26486/jm.v3i2.694.

Guntur, M., Aliyyatunnisa, A., \& Kartono. (2020). Kemampuan Berpikir Kreatif , Kritis , dan Komunikasi Matematika Siswa dalam Academic-Contructive Controversy ( AC ). Prosiding Seminar Nasional Matematika, 3, 385-392. https://journal.unnes.ac.id/ sju/index.php/prisma/ ISSN 26139189\%0A.

Hanik, N. R., Harsono, S., \& Nugroho, A. A. (2018). Penerapan Pendekatan Contextual Teaching And Learning Dengan Metode Observasi Untuk Meningkatkan Hasil Belajar Pada Matakuliah Ekologi Dasar. Jurnal Pendidikan Matematika Dan IPA, 9(2), 127. https://doi.org/10.26418/jpmipa.v9i2.26772.

Isnaeni, I., Muhaemin, M., \& Hasri, H. (2018). Peningkatan Hasil Belajar Matematika Siswa dengan Menerapkan Model Pembelajaran Talking Stick. Al-Khwarizmi: Jurnal Pendidikan Matematika Dan Ilmu Pengetahuan Alam, 5(2), 131-142. https://doi.org/10.24256/jpmipa.v5i2.272.

Mansur, N. (2018). Melatih Literasi Matematika Siswa dengan Soal PISA. Jurnal Prisma, 1(1), 140-144. https://journal.unnes.ac.id/sju/index.php/prisma/\%0AMelatih.

Mardhiyah, R. H., Aldriani, S. N. F., Chitta, F., \& Zulfikar, M. R. (2021). Pentingnya Keterampilan Belajar di Abad 21 sebagai Tuntutan dalam Pengembangan Sumber Daya Manusia. Lectura: Jurnal Pendidikan, 12(1), 29-40. https://doi.org/10.31849/ lectura.v12i1.5813.

Nahdi, S. (2019). Keterampilan Matematika Di Abad 21. Jurnal Cakrawala Pendas, 5(2). https://doi.org/10.31949/jcp.v5i2.1386.

Nurdiana, I. M. (2021). Penggunaan Model Pembelajaran Contextual Teaching And Learning Dengan 
Latihan Keterampilan Yang Benar Untuk Meningkatkan Belajar Bahasa Indonesia Prestasi Siswa. Jurnal Suluh Pendidikan, 19(1), 99-112. https://doi.org/https://doi.org/10.46444/suluhpendidikan.v19i1.240.

Purbaningrum, K. A. (2017). Kemampuan berpikir tingkat tinggi siswa smp dalam pemecahan masalah matematika ditinjau dari gaya belajar. Jurnal Penelitian Pendidikan Matematika, 10(2), 40-49. https://jurnal.untirta.ac.id/index.php/JPPM/article/ viewFile/2029/1571.

Puspita, M., Slameto, S., \& Setyaningtyas, E. W. (2018). Peningkatkan Hasil Belajar Matematika Siswa Kelas 4 SD Melalui Model Pembelajaran Problem Based Learning. Justek: Jurnal Sains Dan Teknologi, 1(1), 120. https://doi.org/10.31764/justek. v1i1.416.

Santoso, K. B. (2020). Penerapan Pendekatan Kontekstual Pada Pembelajaran Matematika Untuk Meningkatkan Prestasi Siswa SMP. Jurnal Pendidikan Matematika, 8(2), 174-179. https://doi.org/10.20527/edumat.v8i1.9213.

Saputri, W., Tiara, A., \& Mawardi, M. (2018). Pengembangan Desain Pembelajaran Tematik Integratif Berbasis Pendekatan Contextual Teaching And Learning (CTL) Kelas 4 Sekolah Dasar. Jurnal Ilmiah Pendidikan Dasar, 4(2), 104. https://doi.org/10.30659/ pendas.4.2.104-114.

Siswono, T. Y. E. (2016). Berpikir Kritis dan Berpikir Kreatif sebagai Fokus Pembelajaran Matematika. Seminar Nasional Matematika Dan Pendidikan Matematika (Senatik 1), 11-26.

Sofia, E. M. (2020). Penerapan Model Contextual Teaching And Learning Terhadap Peningkatkan Keterampilan Menulis Pendapat Pribadi. Kredo : Jurnal Ilmiah Bahasa Dan Sastra, 3(2), 249-262. https://doi.org/10.24176/kredo.v3i2.4783.

Sugandi, A. I., \& Benard, M. (2018). Penerapan Pendekatan Kontekstual Terhadap Kemampuan Pemahaman Dan Komunikasi Matematis Siswa SMP. Jurnal Analisa, 4(1), 16-23. https://journal.uinsgd.ac.id/index.php/analisa/article/view/2364/1916.

Sugandi, A. I., \& Bernard, M. (2018). Penerapan Pendekatan Kontekstual Terhadap Kemampuan Pemahaman Dan Komunikasi Matematis Siswa Smp. Jurnal Analisa, 4(1), 16-23. https://doi.org/10.15575/ja.v4i1.2364.

Suluh, M. (2018). Perspektif Pendidikan Nasional. Jurnal Penelitian Dan Pengkajian Ilmu Pendidikan: ESaintika, 2(1), 1. https://doi.org/10.36312/e-saintika.v2i1.78.

Sumartini, T. S. (2017). Meningkatan Kemampuan Komunikasi Matematis Siswa Melalui Model Pembelajaran Predict Observe Explanation. Jes-Mat (Jurnal Edukasi Dan Sains Matematika), 3(2), 167. https://doi.org/10.25134/jes-mat.v3i2.689.

Wasilati, A., Taruna, R. M., \& Sugiyanto. (2018). Pengaruh Penerapan Model Pembelajaran Contextual Teaching And Learning Terhadap Hasil Belajar IPA. Jurnal Pendidikan Dasar, 6(14). http://jurnal.fkip.unila.ac.id/index.php/pgsd/article/download/16871/12031.

Wirdaningsih, S., Arnawa, I. M., \& Anhar, A. (2017). Pengembangan Perangkat Pembelajaran Matematika dengan Pendekatan Contextual Teaching and Learning untuk Meningkatkan Kemampuan Pemecahan Masalah Peserta Didik Kelas XI. JNPM (Jurnal Nasional Pendidikan Matematika), 1(2), 275. https://doi.org/10.33603/jnpm.v1i2.535.

Yudha, F. (2019). Peran Pendidikan Matematika Dalam Meningkatkan Sumber Daya Manusia Guna Membangun Masyarakat Islam Modern. JPM: Jurnal Pendidikan Matematika, 5(2), 87. https://doi.org/10.33474/jpm.v5i2.2725.

Yuwono, T., Supanggih, M., \& Ferdiani, R. D. (2018). Analisis Kemampuan Pemecahan Masalah Matematika dalam Menyelesaikan Soal Cerita Berdasarkan Prosedur Polya. Jurnal Tadris Matematika, 1(2). https://doi.org/10.21274/jtm.2018.1.2.137-144. 